\title{
The Pattern of Activities and the use of Sex-Performance Enhancing Drugs among Commercial Drivers in Ile Ife Osun State Nigeria
}

\author{
Article by Akinyemi Patrick Ayodeji \\ Department of Community Health, Obafemi Awolowo University Teaching Hospital Complex, \\ Nigeria \\ E-mail:kindepat@yahoo.com
}

\begin{abstract}
Objectives: This research work aimed at assessing prevalence and pattern of drug use for enhancement of daily and sexual activities among commercial drivers in Ile-Ife, Osun State.

Methodology: a descriptive cross-sectional study designed was utilized. A semi-structured interviewer administered questionnaire was used to obtain data from 240 commercial drivers. Data obtained include socio-demographic variables, drug use for daily activity enhancement, the pattern of perceived sexual challenges, usage of the drug for sexual performance enhancement and willingness accept counselling. Data were analysed using Statistical Program for the Social Sciences (SPSS) version 20 and a p-value of $<0.05$ was considered to be statistically significant.

Result: Though $67.9 \%$ believe their activities can be enhanced only $57.1 \%$ do take any psychoactive substance. Prevalence of alcohol consumption was $55.8 \%$ and it is the most commonly abused substance to enhance their daily activity performance. Most common means of sexual performance enhancement was the use of herbal mixture (20.3\%). Worry about sexual performance, daily activity enhancement, smoking, and alcoholism are predictors of sexual performance enhancing drug usage. A number of sexual partners, age and religion were not significant factors in the use of sexual performance enhancement drugs.

Conclusion: commercial drivers are one of the groups at risk of substance abuse in our society. There is a need for behavioural change communication for this group and create a more suitable environment for counselling on the sex related matters in the health facilities. The existing law prohibiting sales of a psychoactive substance in the motor parks should be enforced.
\end{abstract}

Keywords: commercial drivers, herbal mixture, psychoactive substance, sexual dysfunction.

\section{Introduction}

In Nigeria, there has been a rapid increase in the prevalence of psychoactive substance use, especially alcohol for the purpose of performance enhancement. The prevalence increased from $17.32 \%$ in 2008 to about $40 \%$ in 2016(Adamson, Ogunlesi, Morakinyo, \& Akinhanmi, 2015; NDLEA, 2015). This is commonly used by those working under strenuous conditions in order to cope with their job demands e.g. athletes and manual labourers. The increased stress from job demands which contributes significantly among other factors to (perceived) poor libido and sexual performance has shifted attention to the performance enhancement methods to boost sexual performance.

The use of psychoactive drugs has been documented among commercial drivers in Nigeria and it has been shown to be highly prevalent among intra-city and long distance drivers. The practice of the use of these substances is further enhanced by the sale of the items around the motor park where the drivers usually load passengers. The reasons documented in the past studies for the high prevalence of substance use among this profession include the need to be alert on duty, means of relaxation, and social factors like the effect of peer pressure(Ndikom, Ndikom, \& Uvere, 2014). A qualitative study conducted by Lasebikan and Ayinde among commercial drivers in Ibadan, Nigeria revealed widespread use of alcohol. The commonest brand of alcohol was the fermented adulterated local gin called different local names. 
DOI: $10.21522 / \mathrm{TIJPH} .2013 .05 .04 . \mathrm{Art} 037$

ISSN: $2520-3134$

Focused group discussion with drivers as participants revealed that one of the major reasons for its usage was that it increased sexual urge. Another reason given was the quest to stay awake(Laebikan \& Ayinde, 2012).

Also, a study conducted by Makanjuola et al among tanker drivers in Lagos revealed the predictive factors for substance abuse to include having multiple sexual partners. The current prevalence rate of alcohol use was $57.6 \%$ while the life time use prevalence was put at $71.6 \%$. The common reasons for involvement include pleasure, alertness, imitation of their colleagues and for relaxation(Makanjuola, Aina, \& Onigbogi, 2014). Also in a similar study conducted by Alti-Muazu and Aliyu among commercial motorcyclist in Zaria, Nigeria reveal solution intake, which is usually alcoholic based, has a prevalence of $24.5 \%$. the solution use is second to marijuana (25.8\%). The common factors influencing substance use was the need to stay awake, suppression of fatigue and peer group effect(Muazu \& Aliyu, 2008)

Though there are available drugs and therapies to care for sexual dysfunctions in orthodox medicine, a lot of people have a preference for herbal therapy partly due to associated stigma and psychoactive effect of local remedies because most of the herbal mixtures are alcohol-based. This high demand has led to the rapid flooding of Nigerian markets with various brands of herbal drugs, including locally made and imported ones as well as the refined and unrefined varieties. The challenges of performance enhancer drugs particularly the herbal concoctions were echoed in Nigeria through recent chemical poisoning from the adulterated drugs in some states of the country (Anyanwu, Akinyode, \& Adewole, 2016; Berdjis, 2015).

There has been an increase in the brand of these substances especially alcohol in the recent time. These brands are popular among drivers like other people in the society due to the acclaimed medicinal effects of herbal extracts included in the products. The popular effect which has also attracted consumers is its sexual performance enhancement effects. The alcoholic herbal mixture is commonly sold as both refined and packaged products or locally produced and hawked around the motor parks. In a study conducted by Kehinde and Olusegun among commercial drivers in Osogbo, Nigeria, the prevalence of alcoholic herbal mixture intake was $53.6 \%$ and $43.2 \%$ in the past one year and last one month prior to the study(Kehinde \& Olusegun, 2012).

Several efforts have been made to ban alcoholic drink around motor parks by the government due to its adverse effect on both the drivers and passengers especially vehicular and pedestrian road traffic injuries. The effect of the enacted policies has not been felt due to factors like poor enlightenment, enforcement, and evaluation (Ayodele, 2017; Okafor, 2015; Williams, 2015).

Much focus has been on the effect of the psychoactive drug on accident, indication, and pattern for its usage. There has however been little focus on the perceived sexual performance enhancement which is one of the major underline factors for the recent rise in the prevalence of the drug abuse. This study will assess the pattern of psychoactive drug usage in relation to enhancement of sexual performance among both intra-city and long distance drivers. The study will also assess the pattern of perceived sexual dysfunction among the study population which has been ascribed to be the cause of increasing prevalence of herbal-alcoholic drink consumption among the young and middle age group in the society.

\section{Methodology}

\section{Description of the study area}

This study was conducted among commercial drivers in Ile-Ife, Osun State in southwestern Nigeria. The Ile-ife town comprises two local government areas (LGA) namely; Ife Central and Ife East local governments. Both Ife Central local government and Ife East area are located in the Osun East senatorial zone and have a population of 167,204 and 161,246 respectively. The Central local government has 11 administrative wards while Ife East local government has 10 wards. The town is mainly inhabited by people of the Yoruba tribal origin though other ethnic groups such as the Hausa, Igbos, and Urhobos may be found. The main religions are Christianity, Islam and traditional worship and Ile-Ife is one of the largest towns in Osun state. The town has two universities and a teaching hospital (Obafemi Awolowo 
University Teaching Hospitals Complex). The town also has other health care facilities with the primary health care facilities evenly distributed at ward level and a general hospital (secondary health care facilities). The town has various motor parks for vehicle plying various routes of the countries and usually serves as the meeting points for the drivers and it is also utilized for the administrative purposes of the driver's association, National Union of Road Transport Workers (NURTW).

\section{Study population}

The study population was the commercial drivers, intra-city, inter-state and other long distance drivers, who live in the study area. Drivers who brought passengers from other towns and states were excluded from the study.

\section{Study design}

\section{Descriptive cross sectional study}

\section{Sampling methods and sample size}

The town for the study was selected based on proximity and ease of access to the target population. The willing drivers were enrolled into the study at the weekly meetings of various motor parks after obtaining permission from the executives of the driver's union of each park. The intra-city drivers especially those working on the campuses of the tertiary institutions in the study area were enrolled and interviewed at their convenient time while waiting for their turn to pick passengers.

The size was determined using:

$$
\begin{aligned}
& \mathrm{n}=\mathrm{Z}^{2} \mathrm{pq} / \mathrm{d}^{2} \\
& \mathrm{n}=\frac{1.96^{2} \times 0.39 \times 0.61}{0.05^{2}} \\
& \mathrm{n}=\frac{3.8476 \times 0.39 \times 0.61}{0.0025}
\end{aligned}
$$

Where:

$\mathrm{z}=$ standard normal deviate usually set at 1.96

$\mathrm{p}=$ proportion in the target population estimated to have certain characteristics

$\mathrm{q}=1-\mathrm{p}$

$\mathrm{d}=$ degree of freedom $=0.05$

$\mathrm{p}=$ prevalence of drug abuse in Nigeria $=39 \%$ (NDLEA, 2016)

$\mathrm{z}=1.96$

$\mathrm{p}=39 \%=0.39$

$\mathrm{q}=1-\mathrm{p}=0.61$

$\mathrm{n}=366$

Leslie-fishers formula for population less than 10000

$\mathrm{Nf}=$ desired sample size when population is $<10000$

$\mathrm{n}=$ desired sample size when population is $>10000$

$\mathrm{N}=$ estimated population size (Population of Registered NURTW members) $=650$

$\mathrm{Nf}=\frac{\ldots \mathrm{n} \ldots}{1+\mathrm{n} / \mathrm{N}}$

$\mathrm{n}=\underline{366}$

$1+366 / 650$

$\mathrm{n}=124.9=233$

\section{Study tool}

A questionnaire was designed containing sections for sociodemographic variables, questions to elicit underline sexual dysfunction, knowledge of causes of sexual dysfunction and common therapy adopted by the respondents. 
DOI: $10.21522 /$ TIJPH.2013.05.04.Art037

ISSN: $2520-3134$

\section{Method of data collection}

Data was collected using semi structured interviewer administered the questionnaire. The respondents were interviewed in the comfortable area of the motor park after their meetings

\section{Data analysis}

Data were analysed using SPSS version 20. Frequency and percentage were used to summarise univariate data. Statistical significance was set at an alpha level of 0.05 .

\section{Result}

A total number of 240 drivers were enrolled into the study. All respondents were male with mean age of 41.85 .

Sociodemographic variables

\begin{tabular}{ll}
\hline Characteristics & Frequency N $(\%)$ \\
\hline Religion & \\
Christianity & $107(44.6)$ \\
Islam & $133(55.4)$ \\
Marital Status & \\
Single & $20(8.3)$ \\
Married & $219(91.3)$ \\
Divorcee & $1(0.4)$ \\
Number of wives & \\
0 & $18(7.5)$ \\
1 & $107(44.6)$ \\
2 & $102(42.5)$ \\
3 & $7(2.9)$ \\
4 & $6(2.5)$ \\
Age group & \\
$21-30$ & $38(15.8)$ \\
$31-40$ & $79(32.9)$ \\
$41-50$ & $78(32.5)$ \\
$51-60$ & $34(14.2)$ \\
$61-70$ & $8(3.3)$ \\
$71-80$ & $3(1.3)$ \\
\hline
\end{tabular}

Drug use pattern

\begin{tabular}{ll}
\hline Characteristics & Frequency N $(\%)$ \\
\hline Regular drug intake & $137(57.1)$ \\
Yes & $103(42.9)$ \\
No & \\
Routinely used drugs & $24(12.2)$ \\
Analgesics & $37(18.8)$ \\
Antibiotics & $42(21.3)$ \\
Hormonal/ steroids & $13(6.6)$ \\
Cough syrup & $81(41.1)$ \\
Herbal mixture & \\
Smoking & $90(37.5)$ \\
Yes & $150(62.5)$ \\
No &
\end{tabular}




\begin{tabular}{ll} 
Alcohol & \\
Yes & $134(55.8)$ \\
No & $105(44.2)$ \\
\hline
\end{tabular}

Out of the 137 respondents that respond in affirmative to using the drug regularly, there were 81 $(41.1 \%)$ responses to use of herbal mixture. This is followed by $42(21.3 \%)$ positive responses to the use of hormonal/steroids. Out of the 90 responses to smoking, $77(66.4 \%)$ gave a positive response to cigarette smoking while there was39 $(33.6 \%)$ positive responses to marijuana.

$163(67.9 \%)$ of the respondents believed that their daily activities could be enhanced while $77(32.1 \%)$ felt their performance cannot be enhanced. Also, 140 (58.4\%) believe sexual performance can be enhanced while 95 (39.6\%) had a view that sexual performance cannot be enhanced, $5(2.1 \%)$ of the respondents had no response.

There was significant association between positive view on daily activity performance enhancement and sexual performance enhancement $\left(\mathrm{X}^{2}=5.971, \mathrm{df}=1, \mathrm{p}=0.015\right)$

Pattern of activities enhancement

\begin{tabular}{ll}
\hline Activities & Frequency N (\%) \\
\hline Daily activity enhancement & $63(20.4)$ \\
Nil & $10(3.2)$ \\
Singing & $78(25.2)$ \\
Alcohol & $60(19.4)$ \\
Smoking & $52(16.8)$ \\
Exercise & $27(8.7)$ \\
Use of medications & $7(2.3)$ \\
Interaction with co-workers & $12(3.9)$ \\
Resting/sleeping & \\
Sexual activity enhancement & $22(8.8)$ \\
Dietary modification & $51(20.3)$ \\
Herbal concoction & $20(8.0)$ \\
Use medications & $25(10.0)$ \\
Pornography movies & $44(17.5)$ \\
Exercise & $4(1.6)$ \\
Hard drug injection & $43(17.1)$ \\
Smoking & $42(16.7)$ \\
Drinking alcohol & \\
Ever use sexual performance & \\
enhancement methods & \\
Yes & \\
No & \\
Discussion of sexual performance & $153(63.7)$ \\
enhancement methods with partners & \\
Yes & \\
No & $49(20.4)$ \\
\hline
\end{tabular}


DOI: $10.21522 / \mathrm{TIJPH} .2013 .05 .04 . \mathrm{Art} 037$

ISSN: $2520-3134$

Perceived aetiology of poor sexual performance and their prevalence

\begin{tabular}{ll}
\hline Characteristics & Frequency N (\%) \\
\hline Perceived etiology & $176(21.2)$ \\
Stress & $158(19.0)$ \\
Illness & $58(7.0)$ \\
Alcoholism & $121(14.6)$ \\
Lack of interest & $62(7.5)$ \\
Small sexual organ & $98(11.8)$ \\
Lack of cooperation from sexual & $128(15.4)$ \\
partners & $30(3.6)$ \\
Low back pain & $129(22.6)$ \\
Side effect of drugs & $136(23.8)$ \\
Prevalence of the perceived & $40(7.0)$ \\
aetiology & $66(11.5)$ \\
Stress & $12(2.1)$ \\
Illness & $71(12.4)$ \\
Alcoholism & $108(18.9)$ \\
Lack of interest & \\
Small sexual organ & $10(1.7)$ \\
Lack of cooperation from sexual & \\
partners & \\
Low back pain & Side effect of drugs
\end{tabular}

Association between usage of sexual performance enhancement drugs and respondents characteristics

\begin{tabular}{|c|c|c|c|}
\hline \multirow[t]{2}{*}{ Characteristics } & \multicolumn{2}{|c|}{ Ever use sexual performance enhancing drugs } & \multirow[t]{2}{*}{ Statistics } \\
\hline & Yes & No & \\
\hline $\begin{array}{l}\text { Religion } \\
\text { Christianity } \\
\text { Islam }\end{array}$ & $\begin{array}{l}43(18.1) \\
44(18.6)\end{array}$ & $\begin{array}{l}61(25.7) \\
89(37.6)\end{array}$ & $\begin{array}{l}X^{2}=1.715 \\
D f=1 \\
P \text { value }=0.19\end{array}$ \\
\hline \multicolumn{4}{|l|}{ Number of wives } \\
\hline 0 & $4(1.7)$ & $14(5.9)$ & $\mathrm{LR}=5.842$ \\
\hline 1 & $41(17.3)$ & $63(26.6)$ & $\mathrm{Df}=1$ \\
\hline 2 & $35(14.8)$ & $67(28.3)$ & $P$ value $=0.211$ \\
\hline 3 & $5(2.1)$ & $2(0.8)$ & \\
\hline 4 & $2(0.8)$ & $4(1.7)$ & \\
\hline $\begin{array}{l}\text { Routine Daily Drug } \\
\text { intake }\end{array}$ & & & $X^{2}=4.104$ \\
\hline Yes & $57(24.1)$ & $78(32.9)$ & $\mathrm{Df}=1$ \\
\hline No & $30(12.7)$ & $72(30.4)$ & $P$ value $=0.043$ \\
\hline $\begin{array}{l}\text { Worry about sexual } \\
\text { performance }\end{array}$ & & & $\mathrm{X}^{2}=4.239$ \\
\hline Yes & $25(10.5)$ & $26(11.0)$ & $\mathrm{Df}=1$ \\
\hline No & $62(26.2)$ & $124(52.3)$ & $\mathrm{P}$ value $=0.04$ \\
\hline Smoking & & & $\mathrm{X}^{2}=11.033$ \\
\hline Yes & $45(19.0)$ & $45(19.0)$ & $\mathrm{Df}=1$ \\
\hline No & $42(17.7)$ & $105(44.3)$ & $P$ value $=0.001$ \\
\hline Alcoholism & & & $X^{2}=5.373$ \\
\hline
\end{tabular}


Texila International Journal of Public Health Volume 5, Issue 4, Dec 2017

\begin{tabular}{|l|l|l|l|}
\hline Yes & $57(24.1)$ & $75(31.6)$ & Df $=1$ \\
\hline No & $30(12.7)$ & $75(31.6)$ & P value $=0.02$ \\
\hline $\begin{array}{l}\text { Will you welcome } \\
\text { counselling session }\end{array}$ & & & $\mathrm{X}^{2}=1.874$ \\
\hline Yes & $76(32.3)$ & $119(50.6)$ & $\mathrm{Df}=1$ \\
\hline No & $11(4.7)$ & $29(12.3)$ & $\mathrm{P}$ value $=0.171$ \\
\hline $\begin{array}{l}\text { Will you welcome } \\
\text { counselling session for } \\
\text { your sexual partners }\end{array}$ & & & $\mathrm{X}^{2}=3.419$ \\
\hline Yes & $67(28.5)$ & $97(41.3)$ & $\mathrm{Df}=1$ \\
\hline No & $20(8.5)$ & $51(21.7)$ & $\mathrm{P}$ value $=0.064$ \\
\hline & & & \\
\hline LR= Likelihood Ratio & & & \\
\hline
\end{tabular}

Association between age group and attitude towards activity enhancement

\begin{tabular}{|c|c|c|c|c|c|c|c|}
\hline \multirow[t]{2}{*}{ Variables } & \multicolumn{6}{|c|}{ Age group } & \multirow[t]{2}{*}{ statistics } \\
\hline & $21-30$ & $31-40$ & $41-50$ & $51-60$ & $61-70$ & $71-80$ & \\
\hline $\begin{array}{l}\text { Daily activity } \\
\text { enhancement drug } \\
\text { intake } \\
\text { Yes } \\
\text { No }\end{array}$ & $\begin{array}{l}9 \\
29\end{array}$ & $\begin{array}{l}57 \\
22\end{array}$ & $\begin{array}{l}39 \\
38\end{array}$ & $\begin{array}{l}24 \\
10\end{array}$ & $\begin{array}{l}5 \\
3\end{array}$ & $\begin{array}{l}3 \\
0\end{array}$ & $\begin{array}{l}\mathrm{LR}=30.846 \\
\mathrm{Df}=5 \\
\mathrm{P} \text { value }= \\
0.0001\end{array}$ \\
\hline $\begin{array}{l}\text { Worry about } \\
\text { sexual } \\
\text { performance } \\
\text { Yes } \\
\text { No }\end{array}$ & $\begin{array}{l}2 \\
35\end{array}$ & $\begin{array}{l}17 \\
62\end{array}$ & $\begin{array}{l}25 \\
52\end{array}$ & $\begin{array}{l}5 \\
29\end{array}$ & $\begin{array}{l}2 \\
6\end{array}$ & $\begin{array}{l}0 \\
3\end{array}$ & $\begin{array}{l}\mathrm{LR}=15.015 \\
\mathrm{Df}=5 \\
\mathrm{P} \text { value }=0.01\end{array}$ \\
\hline $\begin{array}{l}\text { Ever use sexual } \\
\text { performance } \\
\text { enhancement } \\
\text { Yes } \\
\text { No }\end{array}$ & $\begin{array}{l}11 \\
26\end{array}$ & $\begin{array}{l}34 \\
43\end{array}$ & $\begin{array}{l}24 \\
53\end{array}$ & $\begin{array}{l}16 \\
18\end{array}$ & $\begin{array}{l}2 \\
6\end{array}$ & $\begin{array}{l}0 \\
3\end{array}$ & $\begin{array}{l}\mathrm{LR}=8.399 \\
\mathrm{Df}=5 \\
\mathrm{P} \text { value }= \\
0.136\end{array}$ \\
\hline $\begin{array}{l}\text { Felt need for } \\
\text { counselling } \\
\text { Yes } \\
\text { No }\end{array}$ & $\begin{array}{l}29 \\
6\end{array}$ & $\begin{array}{l}63 \\
16\end{array}$ & $\begin{array}{l}70 \\
7\end{array}$ & $\begin{array}{l}27 \\
7\end{array}$ & $\begin{array}{l}6 \\
2\end{array}$ & $\begin{array}{l}0 \\
3\end{array}$ & $\begin{array}{l}\mathrm{LR}=15.775 \\
\mathrm{Df}=5 \\
\mathrm{P} \text { value }= \\
0.008\end{array}$ \\
\hline $\begin{array}{l}\text { Felt need for } \\
\text { counselling for } \\
\text { sexual partners } \\
\text { Yes } \\
\text { No }\end{array}$ & $\begin{array}{l}22 \\
13\end{array}$ & $\begin{array}{l}53 \\
26\end{array}$ & $\begin{array}{l}57 \\
20\end{array}$ & $\begin{array}{l}26 \\
8\end{array}$ & $\begin{array}{l}6 \\
2\end{array}$ & $\begin{array}{l}0 \\
3\end{array}$ & $\begin{array}{l}\mathrm{LR}=9.418 \\
\mathrm{Df}=5 \\
\mathrm{P} \text { value }= \\
0.083\end{array}$ \\
\hline
\end{tabular}

\section{Discussion}

A total of 240 respondents were enrolled and studied. The respondents are all of Yoruba tribe which is the dominant tribe in the study area.

The prevalence of alcohol consumption was $55.8 \%$. This is similar to the findings in some past studies in the country (Kehinde \& Olusegun, 2012; Laebikan \& Ayinde, 2012; Makanjuola, et al., 2014; Muazu $\&$ Aliyu, 2008). The actual prevalence may be higher than this as some respondents who consume herbal 
DOI: $10.21522 / \mathrm{TIJPH} .2013 .05 .04 . \mathrm{Art} 037$

ISSN: $2520-3134$

mixture with a high concentration of alcohol did not regard it as alcohol intake but local medicine. Social desirability bias was also envisaged in few cases. There was, however, lower prevalence of alcohol consumption (36.2\%) in the findings of Ndikom et al (Ndikom, et al., 2014). It was also lower, 22.6\%, in the study of Okpataku among long distance drivers in Kaduna. Alcohol based substance use was ranked fourth after caffeinated substances, kola nut and Nicotine containing substances(Okpataku, 2015). However, the low prevalence of alcohol based substance use may due to varying sociocultural belief and dominant religion in the northern part of the country which frowns at the use of any substance with alcohol. The cultural practice, however, favours the use of caffeinated substance and nicotine as the selling of tea is a common small scale business in the study area.

While only $51(21.3 \%)$ of the respondents have had cause to worry about their sexual performance, 87 (36.3\%) have used a form of sexual performance enhancement. This shows that majority use these methods of performance enhancement without any perceived underlying pathology. Commonly used sexual performance enhancement methods were herbal concoction (commonly prepared with alcohol), exercise, smoking and intake of alcohol with $20.3 \%, 17.5 \%, 17.1 \%$ and $16.7 \%$ respectively. The common causes of worry about sexual performance among the respondents were low back pain, perceived small sexual organ and premature ejaculation which account for $39 \%, 23.2 \%$ and $20.7 \%$ of the responses respectively. The high prevalence of back pain could be due to prolonged period of driving with poor sitting position and poor road conditions. The low back pain which accounted for the major proportion of responses to the cause of worry could be well managed by a medical expert without resulting to substance abuse.

The majority of the respondents who are worried about their sexual performance got worried through personal conviction (63.4\%) followed by a complaint from sexual partners (25.4\%). Peer influence contributed the least source of worry (11.3\%). The majority of the respondents did not feel that their conditions could be managed medically but by usage of herbs hence have not sought medical assistance. This shows a gap in knowledge and poor health care facility utilization on sexual problems. Despite this majority of the respondents $(81.3 \%)$ are willing to get counselling on their sexual life while $68.3 \%$ of the respondents will welcome similar counselling for their sexual partners.

The associated factors for the use of performance enhancement medications were the usage of drugs for enhancement of daily activities, worry about sexual performance, smoking, and alcoholism. A number of wives, age and religion were not significant factors in the use of performance enhancing drugs or other methods.

\section{Conclusion}

Commercial drivers are one of the at risk group for substance abuse, especially psychoactive substances. This is due mainly to perceived need to be alert while driving which most respondents believed that it could be attained by use of psychoactive substances like alcohol. This is further encouraged by the indiscriminate display of these substances at the motor parks and poor enforcement of prohibition law. The rapid proliferation of alcoholic based herbal mixture has further encouraged the use of the psychoactive drug as there were claims that the alcoholic based herbal mixtures also enhance sexual performance, in addition, to need for alertness desire by study population. Though the majority of the respondents were not worried about their sexual performance, the substances were still been used because it is the desire of every man to be able to achieve optimal performance.

Mass enlightenment against the use of psychoactive substances especially the alcohol either in plain form or as the herbal mixture is recommended. There is also need for enforcing existing laws banning sales of these substances in the motor parks and adoption of stringent measures by the National Agency for Food and Drug Administration and Control (NAFDAC) in the approval of drugs for consumption. 


\section{Reference}

[1]. Adamson, T. A., Ogunlesi, A. O., Morakinyo, O., \& Akinhanmi, A. O. (2015). Descriptive National Survey of Substance use in Nigeria. Journal of Addiction Research and Therapy.

[2]. Anyanwu, M. O., Akinyode, F., \& Adewole, A. (2016). Outbreak of methanol poisoning in a semi urban community, Ondo state, southern Nigeria, April-May 2015: A descriptive analysis. International Journal of Infectious Diseases, 45, 216. doi: 10.1016/j.ijid.2016.02.492.

[3]. Ayodele, R. B. (2017). BAN ON ALCOHOLIC DRINK SALES IN MOTOR PARKS: FACTS AGAINST ITS WORKABILITY IN ROAD ACCIDENT PREVENTION IN NIGERIA. [ban, alcohol drinks, accident, drivers]. 2017.

[4]. Berdjis, N. (2015). Nigeria Mystery Outbreak Solved. The Disease Daily, from www.healthmap.org/site/diseasedaily/article/nigeria-mystery-outbreak-solved-24915.

[5]. Kehinde, O. S., \& Olusegun, F. F. (2012). Taking alcohol by deception II: Paraga (alcoholic herbal mixture) use among commercial motor drivers in a south-western Nigerian city. [journal article]. BMC Research Notes, 5(1), 301. doi: 10.1186/1756-0500-5-301.

[6]. Laebikan, V. O., \& Ayinde, O. (2012). Rapid situation assessments of alcohol and substance use among commercial vehicle drivers in Nigeria East African Medical Journal, 89(11).

[7]. Makanjuola, A. B., Aina, O. F., \& Onigbogi, L. (2014). Alcohol and other psychoactive substance use among tanker drivers in Lagos, Nigeria. European Scientific Journal, 10(15).

[8]. Muazu, M., \& Aliyu, A. (2008). Prevalence of psychoactive substances use among commercial Motorcyclistsand its health and social consequences in Zaria, Nigeria. Annal of African Medicine, 7(2).

[9]. Ndikom, C. M., Ndikom, O. B., \& Uvere, E. (2014). Substance Use and Perceived Consequences on Health and Safety among Commercial Motorcyclists in Ibadan North Local Government, Ibadan, Nigeria. NDLEA. (2015). National Drug Control Master Plan (NDCMP) 2015-2019, from www.ndlea.gov.ng.

[10]. Okafor, O. (2015). FRSC bans the sale of alcohol in motor parks in Rivers State, PM News. Retrieved from www.pmnewsnigeria.com/2015/11/30/frsc-bans-sale-of-alcohol-in-motor-parks-in-rivers.

[11]. Okpataku, C. (2015). Pattern and reasons for substance use among long-distance commercial drivers in a Nigerian city. [Original Article]. Indian Journal of Public Health, 59(4), 259-263. doi: 10.4103/0019-557x.169649

[12]. Williams, Y. (2015). FRSC to ban alcoholic beverages' sale at motor parks, from www.happenings.com.ng/frsc-to-ban-alcoholic-beverages-sale-at-motor-parks/. 